\title{
Mechanism of Vanadium Leaching during Surface Weathering of Basic Oxygen Furnace Steel Slag Blocks: A Microfocus X-ray Absorption Spectroscopy and Electron Microscopy Study
}

\author{
Andrew J. Hobson, ${ }^{\dagger}$ Douglas I. Stewart, ${ }^{\ddagger}$ Andrew W. Bray, ${ }^{\dagger}{ }^{\circledR}$ Robert J. G. Mortimer, ${ }^{\S}$ \\ William M. Mayes," Michael Rogerson," and Ian T. Burke*, ${ }^{*}$ (1) \\ ${ }^{\dagger}$ School of Earth and Environment, and ${ }^{\ddagger}$ School of Civil Engineering, University of Leeds, Leeds, LS2 9JT, U.K. \\ ${ }^{\S}$ School of Animal, Rural and Environmental Sciences, Nottingham Trent University, Brackenhurst Campus, Southwell, \\ Nottinghamshire NG25 0QF, U.K. \\ "School of Environmental Sciences, University of Hull, Hull, HU6 7RX, U.K.
}

Supporting Information

ABSTRACT: Basic oxygen furnace (BOF) steelmaking slag is enriched in potentially toxic $\mathrm{V}$ which may become mobilized in high $\mathrm{pH}$ leachate during weathering. BOF slag was weathered under aerated and air-excluded conditions for 6 months prior to SEM/EDS and $\mu$ XANES analysis to determine $\mathrm{V}$ host phases and speciation in both primary and secondary phases. Leached blocks show development of an altered region in which free lime and dicalcium silicate phases were absent and $\mathrm{Ca}-\mathrm{Si}-\mathrm{H}$ was precipitated $\left(\mathrm{CaCO}_{3}\right.$ was also present under aerated conditions). $\mu$ XANES analyses show that $\mathrm{V}$ was released to solution as $\mathrm{V}(\mathrm{V})$ during dicalcium silicate dissolution and some $\mathrm{V}$ was incorporated into neo-formed $\mathrm{Ca}-\mathrm{Si}-\mathrm{H}$. Higher $\mathrm{V}$

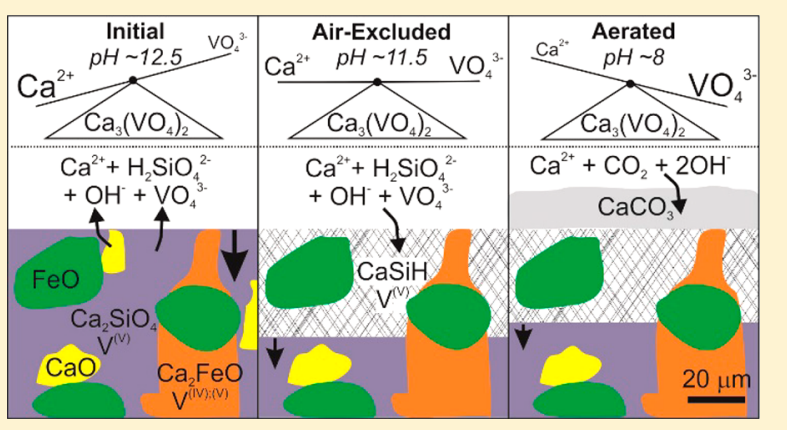
concentrations were observed in leachate under aerated conditions than in the air-excluded leaching experiment. Aqueous $\mathrm{V}$ concentrations were controlled by $\mathrm{Ca}_{3}\left(\mathrm{VO}_{4}\right)_{2}$ solubility, which demonstrate an inverse relationship between $\mathrm{Ca}$ and $\mathrm{V}$ concentrations. Under air-excluded conditions Ca concentrations were controlled by dicalcium silicate dissolution and $\mathrm{Ca}-\mathrm{Si}-\mathrm{H}$ precipitation, leading to relatively high $\mathrm{Ca}$ and correspondingly low $\mathrm{V}$ concentrations. Formation of $\mathrm{CaCO}_{3}$ under aerated conditions provided a sink for aqueous $\mathrm{Ca}$, allowing higher $\mathrm{V}$ concentrations limited by kinetic dissolution rates of dicalcium silicate. Thus, $\mathrm{V}$ release may be slowed by the precipitation of secondary phases in the altered region, improving the prospects for slag reuse.

\section{INTRODUCTION}

Basic oxygen furnace (BOF) steelmaking is a primary method of steelmaking which accounts for $\sim^{2} / 3$ of worldwide steel production. ${ }^{1,2}$ In a basic oxygen converter low carbon steel is produced by blowing oxygen through molten pig iron and recycled scrap steel to remove carbon. BOF slag is the primary byproduct of BOF steelmaking and is produced when limestone (or dolomite) is added to the molten iron as a fluxing agent to draw out impurities. ${ }^{3}$ Because of the large quantities of steel slag produced worldwide (170-250 million metric ton/year ${ }^{4}$ ) reuse has become increasingly important in order to comply with environmental regulations limiting disposal of wastes. Currently steel slag that cannot be recycled in blast furnaces is primarily reused as aggregate in road surfacing and construction due to its high stability and skid resistance, ${ }^{5,6}$ while other uses include neutralization of acidity in soils or mine wastes and possibly for $\mathrm{CO}_{2}$ sequestration. ${ }^{7-10}$ Depending on its precise mineralogy, some steel slag may be unsuitable for reuse, particularly in engineering applications. Steel slag may be enriched in phases such as free lime $(\mathrm{CaO})$ and periclase $(\mathrm{MgO})$ which expand on hydration, resulting in significant volume change. ${ }^{11}$ In situations where slag cannot be reused, or where supply exceeds after-use demand, slag is generally disposed to landfill. ${ }^{12}$

Steel slag formed during primary steelmaking (i.e., from BOF or electric arc furnace (EAF) processes) typically comprises a mixture of $\mathrm{Ca}$ oxides, $\mathrm{Fe}$ oxides, and silicates. The precise chemical composition varies by iron source and processing; however, the bulk chemical composition is relatively consistent between locations worldwide (Table 1 ). Typically BOF slag is dominated by $\mathrm{Ca}, \mathrm{Fe}$, and $\mathrm{Si}$, with minor amounts of $\mathrm{Mg}, \mathrm{Mn}$, and $\mathrm{Al}^{3,13,14}$ The mineralogical composition can be complex but typically contains a range of calcium-containing silicate phases (e.g., Larnite, $\beta-\mathrm{Ca}_{2} \mathrm{SiO}_{4} ;$ Merwinite $\left.\mathrm{Ca}_{3} \mathrm{Mg}\left(\mathrm{SiO}_{4}\right)_{2}\right)$, calcium and aluminum ferrite phases (e.g., Brownmillerite, $\mathrm{Ca}_{2} \mathrm{FeAlO}_{5}$, Srebrodolskite, $\mathrm{Ca}_{2} \mathrm{Fe}_{2} \mathrm{O}_{5}$ ), free $\mathrm{Mg}$ and $\mathrm{Ca}$ oxides (e.g., lime, $\mathrm{CaO}$; periclase, $\mathrm{MgO}$ ) and a refractory oxide solid

Received: February 16, 2017

Revised: May 11, 2017

Accepted: June 19, 2017

Published: June 19, 2017 
Table 1. Chemical Composition of BOF Steel Slags Including XRF Analysis of the Slag Used in This Study. Data Is Presented in Nominal Oxide Format ${ }^{a}$

$\begin{array}{ccccc}\begin{array}{c}\text { major elements } \\ \text { nominal oxide wt \% }\end{array} & \begin{array}{c}\text { Indiana, } \\ \text { USA }^{3}\end{array} & \begin{array}{c}\text { Sweden } \\ \text { Sh }^{14}\end{array} & \begin{array}{c}\text { Taiwan, } \\ \text { China }^{13}\end{array} & \begin{array}{c}\text { Yarborough UK } \\ \text { this study } n=21\end{array} \\ \mathrm{CaO} & 39 & 45 & 39 & 40 \pm 5.4 \\ \mathrm{FeO} & 30 & 22 & 38 & 32 \pm 9.4 \\ \mathrm{SiO}_{2} & 12 & 11 & 7.8 & 14 \pm 3.4 \\ \mathrm{MgO} & 10 & 9.6 & 8.6 & 5.2 \pm 1.1 \\ \mathrm{MnO} & 2.7 & 3.1 & 4.2 & 4.5 \pm 0.8 \\ \mathrm{Al}_{2} \mathrm{O}_{3} & 2.2 & 1.9 & 1.0 & 1.2 \pm 0.4 \\ \mathrm{P}_{2} \mathrm{O}_{5} & 1.0 & 0.52 & \text { n.d. } & 1.3 \pm 0.4 \\ \mathrm{~V}_{2} \mathrm{O}_{5} & \text { n.d } & 2.6 & \text { n.d. } & 0.81 \pm 0.24 \\ \mathrm{TiO}_{2} & 0.40 & 1.4 & 0.94 & 0.30 \pm 0.13 \\ \mathrm{Cr}_{2} \mathrm{O}_{3} & 0.20 & 0.07 & \text { n.d } & 0.24 \pm 0.13 \\ \mathrm{SO}_{3} & 0.12 & \text { n.d } & 0.05 & 0.23 \pm 0.09 \\ \mathrm{TOTAL}_{\mathrm{O} O} & 97.6 & 97.2 & 99.6 & 98.7\end{array}$

${ }^{a}$ Notation: n.d., not determined; n, number of samples.

solution of $\mathrm{Fe}-\mathrm{Mg}-\mathrm{Mn}-\mathrm{Ca}-$ oxides (e.g., Wüstite, $\mathrm{FeO})$.,11,15-17

When stored in contact with water, $\mathrm{CaO}$ and $\mathrm{Ca}$-silicates in BOF slag readily react to generate a high $\mathrm{pH}$ leachate (typically $\mathrm{pH} 10-12.5)$, for example, via eqs 1 and $2:^{18,19}$

$$
\begin{aligned}
& \mathrm{CaO}+\mathrm{H}_{2} \mathrm{O} \rightarrow \mathrm{Ca}^{2+}+2 \mathrm{OH}^{-} \\
& \mathrm{Ca}_{2} \mathrm{SiO}_{4}+2 \mathrm{H}_{2} \mathrm{O} \rightarrow 2 \mathrm{Ca}^{2+}+\mathrm{H}_{2} \mathrm{SiO}_{4}{ }^{2-}+2 \mathrm{OH}^{-}
\end{aligned}
$$

The release of $\mathrm{Ca}^{2+}$ and $\mathrm{H}_{2} \mathrm{SiO}_{4}{ }^{2-}$ to solution can lead to oversaturation with respect to calcium silicate hydrates $(\mathrm{Ca}-$ $\mathrm{Si}-\mathrm{H}$, eq 3), and secondary carbonates in the presence of atmospheric $\mathrm{CO}_{2}\left(\right.$ eq $4^{18}$ ). Spinels (e.g., magnetite, eq 5) and hydroxide phases can also form where di- and trivalent metal ions are released. ${ }^{20}$

$$
\begin{aligned}
& 3 \mathrm{Ca}^{2+}+2 \mathrm{H}_{2} \mathrm{SiO}_{4}^{2-}+2 \mathrm{OH}^{-} \rightarrow 3 \mathrm{CaO} \cdot 2 \mathrm{SiO}_{2} \cdot 3 \mathrm{H}_{2} \mathrm{O} \\
& \mathrm{Ca}^{2+}+\mathrm{CO}_{2}+2 \mathrm{OH}^{-} \rightarrow \mathrm{CaCO}_{3}+\mathrm{H}_{2} \mathrm{O} \\
& \mathrm{Fe}^{2+}+2 \mathrm{Fe}^{3+}+4 \mathrm{H}_{2} \mathrm{O} \rightarrow \mathrm{Fe}_{3} \mathrm{O}_{4}+8 \mathrm{H}^{+}
\end{aligned}
$$

Steel slags usually contain a variety of trace elements from the primary ore that become concentrated by processing. At high $\mathrm{pH}$, several potential toxic metals are solubilized and become mobile in leachate including $\mathrm{Al}, \mathrm{Fe}$, and $\mathrm{V}^{18-21}$ In recent years $\mathrm{V}$ leaching has received significant attention due to its relative enrichment in BOF slag $\left(0.04-1.48 \mathrm{wt} \%{ }^{14,21}\right)$ and the potential mobility and toxicity of $\mathrm{V}(\mathrm{V})$ species in alkaline leachates. $\mathrm{V}$ is present in steel slag in multiple oxidation states ( $\mathrm{V}(\mathrm{III}), \mathrm{V}(\mathrm{IV})$, and $\mathrm{V}(\mathrm{V})^{21,22}$ ); however, there is uncertainty about the exact host phases and the $\mathrm{V}$ oxidation state within those phases, making evaluation of $\mathrm{V}$ leaching behavior difficult. ${ }^{23}$ This uncertainty is compounded by the use of leaching data acquired from powdered specimens, which may be unrepresentative of slag aggregate weathering in civil engineering applications. ${ }^{8,20}$ As a result regulatory bodies, such as the UK Environment Agency, are adopting worst case scenario assumptions when considering $\mathrm{V}$ leaching from steel slags. ${ }^{24}$ This will have an adverse effect on beneficial reuse of slag, and could lead to overly stringent long-term monitoring requirements for landfills.
Previous research has shown that under air-excluded leaching conditions up to $1.7 \%$ of the $\mathrm{V}$ in BOF slag was released to solution. ${ }^{20}$ This is due to the relatively high reactivity of the $\mathrm{V}$ hosting phase, and the prediction that V(III) and V(IV) can be oxidized to $\mathrm{V}(\mathrm{V})$ during slag weathering. ${ }^{17,20,22}$ No data are available concerning leaching of steel slags under aerated conditions that will be more favorable to $\mathrm{V}$ oxidation. Equally, the role of secondary phase formation in controlling $\mathrm{V}$ release is currently unknown, although the potential for aqueous $\mathrm{V}$ to be incorporated into $\mathrm{Ca}-\mathrm{Si}-\mathrm{H}$ has been noted. ${ }^{20}$

A thorough understanding of weathering processes in $\mathrm{BOF}$ slag is essential to enable long-term, cost-effective management and use of steel slag while protecting both the environment and human health from its potentially hazardous components. This study used scanning electron microscopy (SEM) and X-ray absorption near-edge spectroscopy (XANES) to determine the distribution and speciation of $\mathrm{V}$ within BOF steel slag, and to determine whether leachate equilibrium atmosphere affects $\mathrm{V}$ release during slag leaching. This research provides new insights into the distribution of $\mathrm{V}$ within both unweathered and weathered BOF slag, and investigates the mechanisms underpinning enhanced $\mathrm{V}$ leaching and its fate in neo-formed phases.

\section{METHODS}

Sample Collection and Characterization. Basic oxygen furnace (BOF) steel slag was collected in May 2013, within 1 week of its deposition, from British Steel's Yarborough Landfill (Scunthorpe, UK; LAT 5335'22.24" LONG $0^{\circ} 35^{\prime} 41.52^{\prime \prime}$ ). The sample consisted of 50-500 g blocks ( 100 kg total). Subsamples were either cut into smaller $8 \mathrm{~g}$ blocks $(20 \mathrm{~mm} \times$ $10 \mathrm{~mm} \times 10 \mathrm{~mm}$ ) using a diamond saw for use in leaching experiments, or ground to $<150 \mu \mathrm{m}$ powder for compositional analysis. Major and minor element composition was determined using an Olympus X-5000 X-ray fluorescence (XRF) analyzer. Mineralogical analysis was performed using 50-100 mg samples mounted on silicon slides on a Bruker D8 $\mathrm{X}$-ray diffractometer (XRD) using $\mathrm{Cu} \mathrm{K} \alpha$ radiation and scanning between $2^{\circ}$ and $70^{\circ} 2 \theta$.

Leaching Experiments. Two $8 \mathrm{~g}$ slag blocks were placed in a $2 \mathrm{~L}$ graduated glass screw-top bottle containing $2 \mathrm{~L}$ of deionized water (DIW). Air-excluded $\left(\mathrm{O}_{2}\right.$ and $\mathrm{CO}_{2}$-free) conditions were established by purging for $45 \mathrm{~min}$ with $\mathrm{N}_{2}$ gas before the bottle was capped and stored in a Coy anaerobic cabinet $\left(95 \% \mathrm{~N}_{2}: 5 \% \mathrm{H}_{2}\right.$, Coy Ltd. USA). Two further blocks were leached in water in a bottle stoppered with a foam bung and continually aerated with laboratory air using an aquarium pump. Leaching continued for 6 months before the blocks were removed from the bottles and dried under $\mathrm{N}_{2} / \mathrm{H}_{2}$ atmosphere in the Coy Cabinet. The leachate $\mathrm{pH}$ was determined following removal of the blocks using an Orion DualStar $\mathrm{pH} / \mathrm{ISE}$ benchtop meter (Thermo Scientific, USA) with electrodes

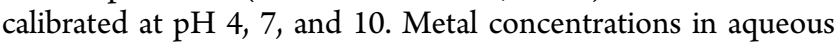
leachate samples $(0.2 \mu \mathrm{m}$; PTFE filtered) were determined (with an analytical uncertainty of $< \pm 3 \%$ ) either on a Thermo iCAP 7400 radial ion-coupled plasma optical emission spectrometer (ThermoFisher Scientific, USA, ICP-OES; major elements), or on a Thermo iCAP Qc ion-coupled plasma mass spectrometer (ThermoFisher Scientific, USA, ICP-MS; minor elements).

Scanning Electron Microscopy. The leached blocks and an unleached control block were cut in half widthwise under water using a diamond saw and the resultant $\sim 1 \mathrm{~cm}^{3}$ blocks were set into epoxy resin. The surface to be examined was then 


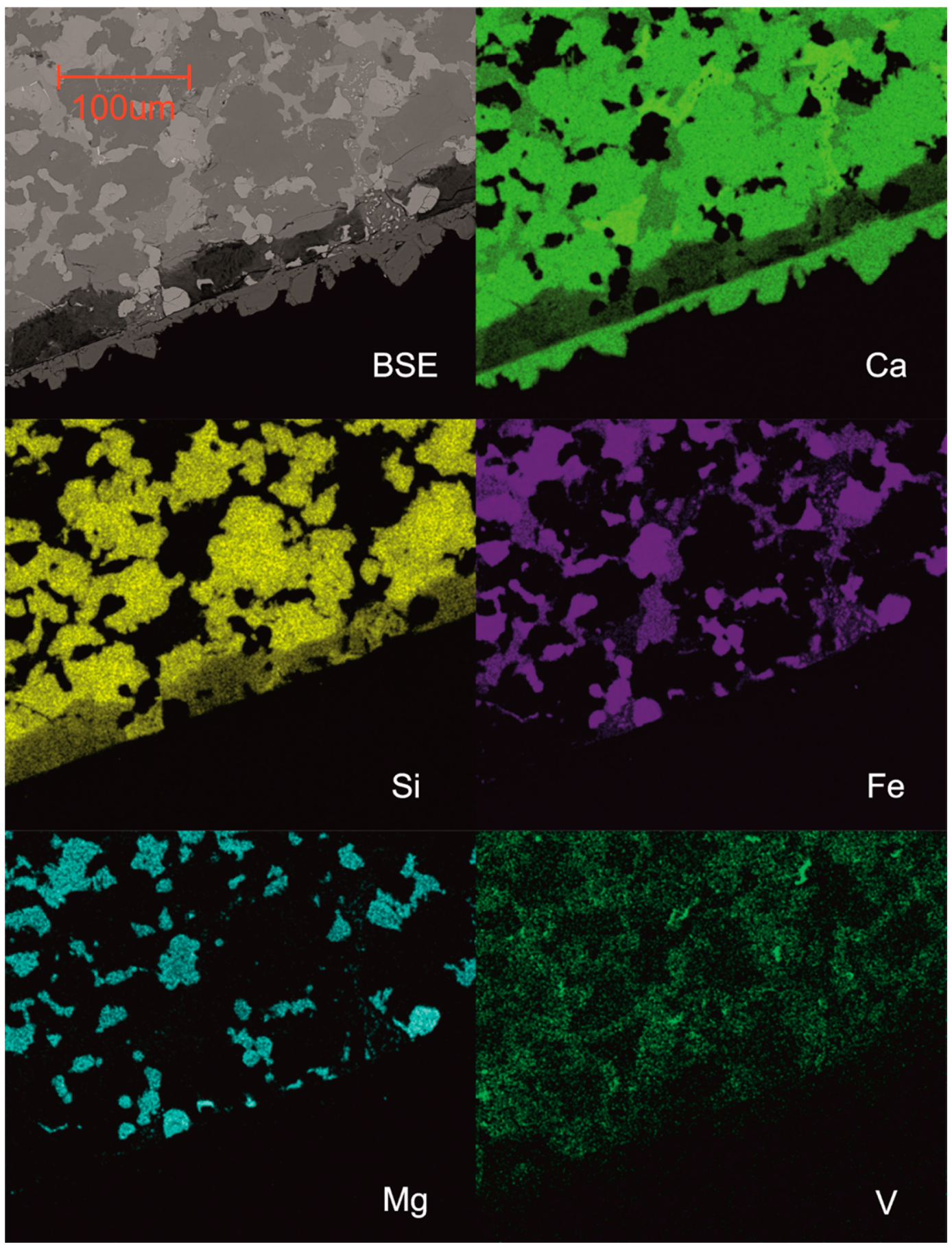

Figure 1. Slag surface structure after 6 months weathering under aerated conditions; backscatter electron image and false color EDS element maps.

polished using a water-free diamond paste to remove the top $1-2 \mathrm{~mm}$ of material potentially exposed to water during cutting. The samples were carbon coated $(\sim 10 \mathrm{~nm})$ and backscatter electron images were collected on a FEI Quanta 650 FEGESEM environmental scanning electron microscope (SEM) equipped with an Oxford Instruments INCA 350 energy-dispersive X-ray spectroscopy system that had an 80 mm X-Max silicon drift detector. Energy-dispersive X-ray spectroscopy (EDS) mapping and quantitative point analysis were processed using the Oxford Instruments AZtec acquisition and analysis software (see Supporting Information (SI) section S1 for further details). False color SEM-EDS composite elemental maps were used to identify phases, and phase composition was subsequently determined both near and remote from the leached surface of each slag block by point counting using randomly oriented $20 \times 20 \mu \mathrm{m}$ grids; ${ }^{25}$ (e.g., SI Figure S1a).

$\boldsymbol{\mu X}$-ray Absorption Spectroscopy. Using the polished blocks described above, $\mu \mathrm{X}$-ray analysis near edge structure ( $\mu$ XANES; $\sim 2 \mu \mathrm{m}$ resolution) spectra were collected at the V K-edge $(5465 \mathrm{eV})$ on beamline I18, Diamond Light Source, UK in February 2016. Standard spectra were collected from a range of laboratory chemicals and aqueous solutions (1000 ppm). Multiple $\mu$ XANES spectra were averaged to improve signal-tonoise ratio, normalized, and plotted using Athena v0.9.24 ${ }^{26}$ (see SI section S2 for detailed methodology). 


\section{RESULTS}

Slag Composition. The elemental composition of the slag was dominated by $\mathrm{Ca}, \mathrm{Fe}$, and $\mathrm{Si}$, with $\mathrm{Mn}$ and $\mathrm{Mg}$ as minor constituents; the $\mathrm{V}$ concentration was $0.45 \pm 0.13$ wt \% (Table 1; SI Table S1). XRD analysis showed that the slag contained Larnite (dicalcium silicate; $\beta-\mathrm{Ca}_{2} \mathrm{SiO}_{4}$ ), brownmillerite (dicalcium aluminoferrite; $\left.\mathrm{Ca}_{2}(\mathrm{Al}, \mathrm{Fe})_{2} \mathrm{O}_{5}\right)$, free lime $(\mathrm{CaO})$, and wüstite (refractory oxide; $\mathrm{FeO}$ ) (SI Figure $\mathrm{S} 4$ ).

SEM Microanalysis. SEM analysis showed that the center of slag blocks consists of an interlocking crystalline matrix (Figure 1). EDS mapping showed that each subregion within the matrix had relatively uniform composition and four different chemically discrete phases were identified. Quantitative EDS spot analyses (e.g., SI Figure S1b-e; SI Table S2) was used to further characterize these phases. The first phase had an average molar $\mathrm{Ca} / \mathrm{Si}$ ratio of $2.2 \pm 0.1$, corresponding to the dicalcium silicate phase identified by $\mathrm{XRD}$; this phase also contained $\mathrm{P}, \mathrm{V}$, and trace Fe. The composition of the second phase was dominated by $\mathrm{Ca}, \mathrm{Al}$, and $\mathrm{Fe}$ suggesting that it is the dicalcium aluminoferrite phase identified by XRD; this phase also contained $\mathrm{Mn}, \mathrm{Ti}, \mathrm{Mg}, \mathrm{Cr}$, and $\mathrm{V}$. EDS spot analysis indicated that the third phase was principally $\mathrm{CaO}$, but this free lime phase was also substituted with $\mathrm{Mn}$ and Fe. The fourth phase contained $\mathrm{FeO}, \mathrm{MnO}, \mathrm{MgO}$, and $\mathrm{CaO}$, suggesting it is a refractory oxide solid solution (e.g., a phase indistinguishable from Wüstite by XRD). The proportion of each phase in the slag (by volume) is shown in Table 2. Vanadium was present in

Table 2. Point Counting Analysis of Phase Distribution (\% by Volume) in the Unweathered Slag and the Altered Surface Regions

\begin{tabular}{lccc}
\multicolumn{1}{c}{ phases } & $\begin{array}{c}\text { unweathered } \\
\text { slag }\end{array}$ & $\begin{array}{c}\text { altered region } \\
\text { aerated } \\
\text { conditions }\end{array}$ & $\begin{array}{c}\text { altered region air- } \\
\text { excluded } \\
\text { conditions }\end{array}$ \\
$\mathrm{Ca}_{2} \mathrm{SiO}_{4}$ & $57 \pm 3$ & n. d. & n. d. \\
$\mathrm{Ca}-\mathrm{Si}-\mathrm{H}$ & n.d. & $64 \pm 3$ & $63 \pm 3$ \\
wüsite & $21 \pm 3$ & $20 \pm 3$ & $20 \pm 3$ \\
$\mathrm{Ca}_{2}(\mathrm{Fe}, \mathrm{Al})_{2} \mathrm{O}_{5}$ & $13 \pm 3$ & $10 \pm 3$ & $14 \pm 3$ \\
lime & $8 \pm 2$ & n.d. & n. d. \\
$\mathrm{Ca}-\mathrm{Si}-\mathrm{H} / \mathrm{Fe}-\mathrm{O}$ & n.d. & $6 \pm 2$ & $4 \pm 2$ \\
total counts & 1012 & 920 & 848
\end{tabular}

${ }^{a}$ Where present, the $\mathrm{CaCO}_{3}$ layer was excluded from this analysis. n.d., not detected.

only the dicalcium silicate $(0.44 \pm 0.23 \mathrm{wt} \%)$ and the dicalcium aluminoferrite phase $(1.14 \pm 0.14$ wt $\%)$ and not detectable in the free lime and Wüstite phases.

SEM imaging of experimental blocks showed the presence of a compositionally distinct altered region at the block surface that was absent in unweathered samples (Figure 1; SI Figure S5). EDS analysis showed that this region was depleted in both $\mathrm{Ca}$ and $\mathrm{Si}$. High resolution imaging showed that dicalcium silicate is depleted and free lime is absent, but the refractory oxide and dicalcium aluminoferrite phases appear largely unaltered (Table 2). A low density $\mathrm{Ca}$ and $\mathrm{Si}$ containing phase $(\mathrm{Ca} / \mathrm{Si}$ ratio of $2.1 \pm 0.4)$ is observed in this region, the composition of which is consistent with calcium silicate hydrate phases ( $\mathrm{Ca}-\mathrm{Si}-\mathrm{H}$; SI Figure S6). ${ }^{27,28}$ Occasional blade-like morphology is consistent with $\mathrm{Ca}-\mathrm{Si}-\mathrm{H}(\mathrm{II})$, which has an imperfect Jennite-like structure and a $\mathrm{Ca} / \mathrm{Si}$ ratio in the range 1.5-2.2. ${ }^{29,30}$ This $\mathrm{Ca}-\mathrm{Si}-\mathrm{H}$ phase also contained $\mathrm{V}(0.70 \pm$ 0.57 wt \% SI Table S2), Fe and P (SI Figure S1f). The thickness of this altered region was $38 \pm 11(n=92)$ and $45 \pm$ $14 \mu \mathrm{m}(n=76)$ in the aerated and air-excluded tests, respectively, and this difference is statistically significant (Mann-Whitney $U, p=<0.001$ ). Blocks from the aerated experiment had an additional continuous 10-30 $\mu \mathrm{m}$ layer outside the altered region, which consisted of blocky crystals that contained principally $\mathrm{Ca}, \mathrm{C}$, and $\mathrm{O}$ with trace $\mathrm{P}$ consistent with precipitation of $\mathrm{CaCO}_{3}$ (Figure 1, SI Figure S1g).

Leachate Composition. The $\mathrm{pH}$ values and the concentration of key elements in the leachate after 6 months are shown in Table 3. Both leachates were dominated by $\mathrm{Ca}$ and $\mathrm{Si}$.

Table 3. Leachate Composition Determined after Six Months in the Aerated and Air-Excluded Slag Leaching Experiments

\begin{tabular}{lcc} 
& Aerated & Air-excluded \\
$\mathrm{pH}$ & 8.0 & 11.9 \\
Major Ions $\left(\mathrm{mg} \mathrm{L}^{-1}\right)$ & & \\
$\mathrm{Ca}$ & 23.5 & 85.2 \\
$\mathrm{Si}$ & 23.4 & 29.5 \\
$\mathrm{Mg}$ & 0.1 & 0.1 \\
$\mathrm{~K}$ & 0.2 & 0.4 \\
$\mathrm{Na}$ & 1.7 & 2.4 \\
$\mathrm{Minor}$ Ions $\left(\mu \mathrm{g} \mathrm{L}^{-1}\right)$ & & \\
$\mathrm{Al}$ & $<2$ & 390 \\
$\mathrm{Cr}$ & 6.5 & 9.6 \\
$\mathrm{Fe}$ & 122.7 & 251.3 \\
$\mathrm{Li}$ & $<0.1$ & $<0.1$ \\
$\mathrm{Mn}$ & 8.5 & 13.1 \\
$\mathrm{~V}$ & 859.1 & 492.8 \\
\hline
\end{tabular}

The $\mathrm{pH}$ values of the leachate from the aerated and airexcluded systems were 8.0 and 11.9 , and $\mathrm{V}$ concentrations were $859 \mu \mathrm{g} \mathrm{L}^{-1}$ and $493 \mu \mathrm{g} \mathrm{L}^{-1}$, respectively.

$\boldsymbol{\mu}$ XANES Analysis. Representative XANES spectra for each $\mathrm{V}$-bearing phase in experimental samples and standards are shown in Figure 2a. Vanadium K-edge $\mu$ XANES spectra $(n=$ 49) collected from all phases present have a prominent preedge peak at $5470 \mathrm{eV}( \pm 0.25 \mathrm{eV})$. Normalized intensity $( \pm 0.10)$ of the pre-edge peak for spectra collected from $\mathrm{V}$ bearing phases range from 0.36 to 1.00 in dicalcium silicate, 0.17 to 1.00 in dicalcium aluminoferrite, and 0.61 to 0.94 in the $\mathrm{Ca}-\mathrm{Si}-\mathrm{H}$ (Figure $2 \mathrm{~b})$. The main absorption edge $\left(E_{1 / 2}\right.$, the point at which absorption reaches $50 \%$ of normalized absorption) varied from 5479.0 to $5482.3 \mathrm{eV}$ in dicalcium silicate, 5478.9 to $5482.3 \mathrm{eV}$ in dicalcium aluminoferrite and from 5480.1 to $5482.2 \mathrm{eV}$ in $\mathrm{Ca}-\mathrm{Si}-\mathrm{H}$ (Figure 2b).

\section{DISCUSSION}

Reactivity of Phases during Weathering. The development of a compositionally distinct region at the surface of the blocks shows alteration of slag phases has taken place during the six-month leaching experiments. SEM imaging and EDS analyses show depletion of dicalcium silicate and complete dissolution of free lime phases in this altered region, hence these must be considered the reactive phases during slag weathering (eqs 1 and 2). The Fe-rich phases (dicalcium aluminoferrite and refractory oxide) showed no evidence of alteration over the time period of the experiments. The thickness of the altered region was significantly greater in airexcluded samples than aerated equivalents, indicating that the presence or absence of air is a significant factor contributing to 
A)

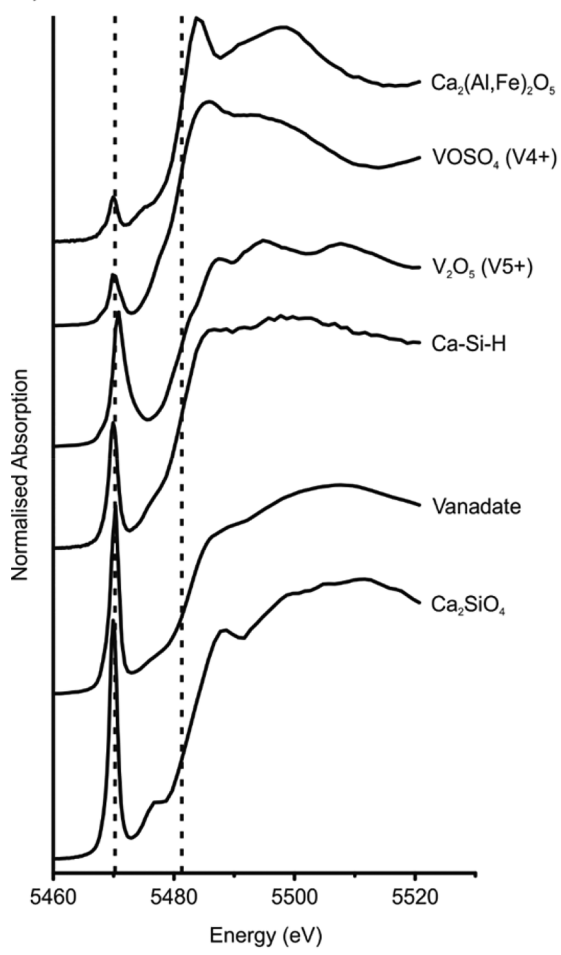

B)

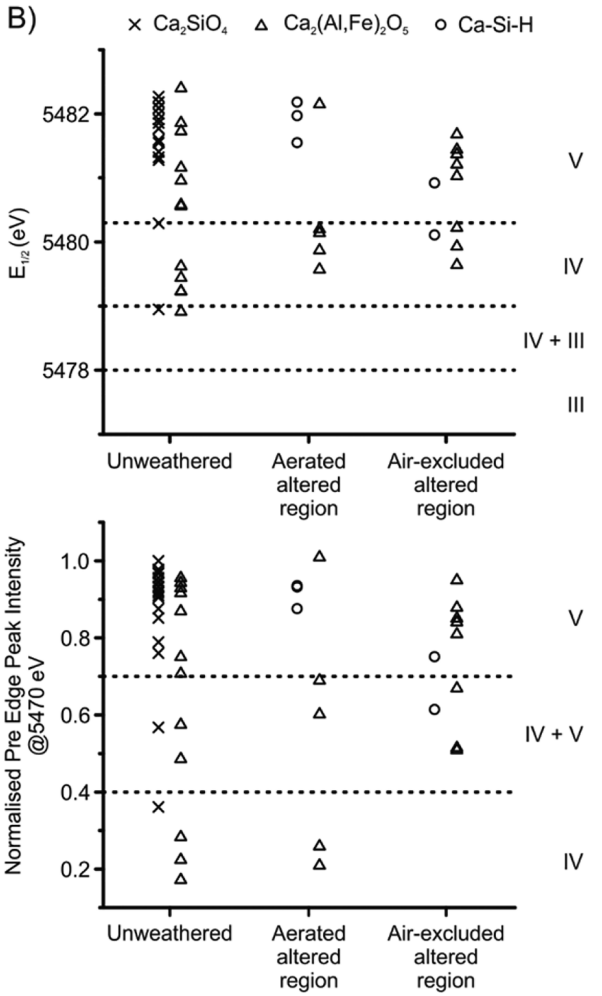

Figure 2. (A) Representative V K-edge $\mu$ XANES spectra collected from V-containing slag phases and standards; and (B) $E_{1 / 2}$ position and normalized pre-edge peak height intensity determined from all data collected from slag blocks.

the rate and overall extent of altered region formation on short time-scales.

Secondary Phase Formation $\mathrm{Ca}-\mathrm{Si}-\mathrm{H}$ and $\mathrm{CaCO}_{3}$. Dissolution of dicalcium silicate in the slag blocks released Ca and $\mathrm{Si}$ to solutions, which results in precipitation of a $\mathrm{Ca}-\mathrm{Si}-\mathrm{H}$ phase (eq 3) in place of dicalcium silicate in the altered region under both aerated and air-excluded conditions. Low elemental totals from EDS spot analyses (SI Table S2) of $\mathrm{Ca}-\mathrm{Si}-\mathrm{H}$ phases represent areas with high volumes of carbon-rich resin (as carbon is not determined in EDS analysis). This indicates that $\mathrm{Ca}-\mathrm{Si}-\mathrm{H}$ has a porous structure which will allow diffusion of water and ions through the altered region. Thus, it is likely that dicalcium silicate dissolution switched from initially solubility limited to a diffusion limited process as the altered region developed (i.e., the rate of removal of $\mathrm{Ca}$ and $\mathrm{Si}$ from the slag surface controls rate of weathering). Therefore, formation of $\mathrm{Ca}-\mathrm{Si}-\mathrm{H}$ may have an armoring effect on slag, slowing the rate of dicalcium silicate weathering. Pseudomorphs of lime were also found in the altered region, containing $\mathrm{Ca}, \mathrm{Si}$, $\mathrm{Fe}, \mathrm{Mn}$, and $\mathrm{O}$ (SI Figure S1). This may represent a distinct $\mathrm{Fe}(\mathrm{Mn})$-substituted $\mathrm{Ca}-\mathrm{Si}-\mathrm{H}$ phase or coprecipitated $\mathrm{Ca}-\mathrm{Si}-$ $\mathrm{H}$ and $\mathrm{Fe}(\mathrm{Mn})$ spinel phases. Formation of $\mathrm{CaCO}_{3}$ is only observed in aerated experiments, as it requires the in-gassing of atmospheric $\mathrm{CO}_{2}$ to allow aqueous $\mathrm{Ca}$ to precipitate. ${ }^{19}$ Such ingassing consumes $\mathrm{OH}^{-}$, which reduces the $\mathrm{pH}$ (eq 4) and significantly lowers the $\mathrm{Ca}$ concentration in the aerated leachate.

$\mathrm{Si}$ was used to track elemental mass balance during the replacement of dicalcium silicate by an approximately equal volume of $\mathrm{Ca}-\mathrm{Si}-\mathrm{H}$ (Table 2). Comparing the mean $\mathrm{Si}$ concentration found within the dicalcium silicate phase (13.2 \pm 0.7 wt \%; SI Table S2) with that found within the $\mathrm{Ca}-\mathrm{Si}-\mathrm{H}$ phase $(4.7 \pm 2.2 \mathrm{wt} \%)$ indicates that only $36 \pm 22 \%$ of the $\mathrm{Si}$ present in the original dicalcium silicate phase was retained in the $\mathrm{Ca}-\mathrm{Si}-\mathrm{H}$ Layer. A mass balance using $\mathrm{Ca}$ concentrations produces a similar result $(33 \pm 18 \%$; SI Table S2). Thus, during weathering of dicalcium silicate in these experiments, very approximately one-third of the weathered $\mathrm{Si}$ (and $\mathrm{Ca}$ ) was retained as $\mathrm{Ca}-\mathrm{Si}-\mathrm{H}$ and two-thirds was released as ions to solution. The Si found in the $2 \mathrm{~L}$ solution at the end of the experiments (47 and $59 \mathrm{mg}$; Table 3 ) equates to approximately 4.5 or $5.6 \%$ of the total Si present in the original $2 \times 8 \mathrm{~g}$ blocks in the aerated and air-excluded experiments, respectively (i.e., the slag contained $6.5 \pm 1.6 \mathrm{wt} \% \mathrm{Si}$; SI Table S1). If the $\mathrm{Si}$ found in solution is assumed to represent two-thirds of the original dicalcium silicate that was weathered, then as much as 6.7 or $8.4 \%$ of the dicalcium silicate in the blocks was involved in the weathering reaction. The volume of the alteration layer calculated from thickness measurements $\left(38 \mathrm{~mm}^{3}\right.$, aerated; 45 $\mathrm{mm}^{3}$, air-excluded) equates to only 1.9 or $2.3 \%$ of the total block volume $\left(2000 \mathrm{~mm}^{3}\right)$. This considerable discrepancy indicates that the reaction must have involved weathering of dicalcium silicate via the internal porosity (BOF slag has high porosity of $4-6 \%{ }^{31}$ ) and along fractures.

V Speciation, Behavior, and Controls on Solubility. The position of the main absorption edge $\left(E_{1 / 2}\right)$ and the normalized pre-edge peak intensity determined from $\mathrm{V} \mathrm{K}$-edge XANES spectra can be used to define $\mathrm{V}$ oxidation state. ${ }^{32}$ Spectra collected from the BOF slag samples indicate that $\mathrm{V}$ is present as either $\mathrm{V}(\mathrm{IV})$ or $\mathrm{V}(\mathrm{V})$ (Figure $2 \mathrm{~b}$ ). Vanadium is present throughout the dicalcium silicate phase as $\mathrm{V}(\mathrm{V})$ in tetrahedral co-ordination ${ }^{22}$ with just one spectrum displaying characteristics of $\mathrm{V}(\mathrm{IV})$; however, this was taken from a region of high $\mathrm{V}$ concentration and may not be representative of the bulk phase. In the dicalcium aluminoferrite phase $\mathrm{V}$ is present as both $\mathrm{V}(\mathrm{IV})$ in octahedral co-ordination ${ }^{22}$ and $\mathrm{V}(\mathrm{V})$ in 
tetrahedral co-ordination. Both oxidation states can be accommodated in dicalcium aluminoferrite because it contains octahedral $\mathrm{Fe}$ (III) sites into which $\mathrm{V}(\mathrm{IV})$ can readily substitute (due to similar size and charge) and tetrahedral Al sites into which $\mathrm{V}(\mathrm{V})$ substitutes. ${ }^{33}$ No V(III) was detected within the slag.

Spectra from the neo-formed $\mathrm{Ca}-\mathrm{Si}-\mathrm{H}$ phase generally show tetrahedral V(V) with only one exception of V(IV). Ca$\mathrm{Si}-\mathrm{H}$ phases, such as dicalcium silicate, contain tetrahedral $\mathrm{Si}$ sites which can easily accommodate the tetrahedral vanadate ions, but the phases do not contain any octahedral anion sites. ${ }^{34}$ The presence of $\mathrm{V}(\mathrm{V})$ in $\mathrm{Ca}-\mathrm{Si}-\mathrm{H}$ suggests that some of the vanadate released to solution by dicalcium silicate dissolution has been reincorporated into $\mathrm{Ca}-\mathrm{Si}-\mathrm{H}$.

XANES spectra collected from BOF slag show little, if any depletion of $\mathrm{V}(\mathrm{IV})$ in the altered region. Also, the small quantities of $\mathrm{V}(\mathrm{IV})$ that have been observed in the dicalcium silicate phase are unlikely to be sufficient to significantly contribute to $\mathrm{V}$ release. Hence, the results do not support oxidation of $\mathrm{V}(\mathrm{IV})$ to $\mathrm{V}(\mathrm{V})$ as a mechanism contributing to enhanced vanadium leaching under aerated conditions, a scenario which would require significant dissolution of dicalcium aluminoferrite (the principal host phase for $\mathrm{V}(\mathrm{IV})$ ), which is not observed. Thus, over time scales measured in months, it is proposed that essentially all $\mathrm{V}$ released to solution must originate from the dicalcium silicate phase as $\mathrm{V}(\mathrm{V})$, which is predicted to be soluble as aqueous vanadate species at the measured solution $\mathrm{pH}^{35,36}$

Dissolution of $6-8 \%$ of the dicalcium silicate present in the original $8 \mathrm{~g}$ blocks would produce a calculated maximum $\mathrm{V}$ concentration in solution of approximately $12 \mathrm{mg} \mathrm{L}^{-1}$. However, total $\mathrm{V}$ present in solution is less than $10 \%$ of that value. The $\mathrm{Ca}-\mathrm{Si}-\mathrm{H}$ phase has taken up some of the $\mathrm{V}$ released, but due to the relatively poorly ordered nature of $\mathrm{Ca}-$ $\mathrm{Si}-\mathrm{H}$ phases ${ }^{37}$ this uptake is expected to be unselective, with $\mathrm{V}$ incorporation approximately stoichiometric with the $\mathrm{V} / \mathrm{Si}$ ratio in solution at the time of formation. However, the proportion of $\mathrm{Si}$ released by dicalcium silicate dissolution that remains in solution was proportionally much greater than $\mathrm{V}(\sim 65 \%$ vs $<10 \%$; see Discussion above). Also aqueous $\mathrm{V}$ concentrations were much higher in the aerated test, despite evidence that total dicalcium silicate dissolution was probably $\sim 20 \%$ lower in this test. Therefore, aqueous $\mathrm{V}$ concentrations are not well explained by uptake to the $\mathrm{Ca}-\mathrm{Si}-\mathrm{H}$ phase alone. Previous modeling of $\mathrm{V}$ solubility in BOF leachates has highlighted the role of calcium vanadate phases in controlling $\mathrm{V}$ concentration, ${ }^{8,20,38,39}$ with $\mathrm{Ca}_{3}\left(\mathrm{VO}_{4}\right)_{2}\left(\log K_{\mathrm{sp}}=-17.97\right)$ identified as the relevant phase at high $\mathrm{pH}$.

$$
3 \mathrm{Ca}^{2+}+2 \mathrm{VO}_{4}{ }^{3-} \rightleftharpoons \mathrm{Ca}_{3}\left(\mathrm{VO}_{4}\right)_{2}
$$

Therefore, the maximum possible aqueous $\mathrm{V}$ concentration will be inversely proportional to the aqueous $\mathrm{Ca}^{2+}$ concentration. The variation in $\mathrm{V}$ seen under different experimental conditions (Figure 3) can be explained by the different phases that control the aqueous $\mathrm{Ca}^{2+}$ concentration. Under airexcluded conditions, equilibrium with $\mathrm{Ca}-\mathrm{Si}-\mathrm{H}$ phases will permit relatively high aqueous $\mathrm{Ca}^{2+}$ concentrations to develop, which result in vanadate concentrations either at or very close to the solubility limit of $\mathrm{Ca}_{3}\left(\mathrm{VO}_{4}\right)_{2}$ which limits the concentration of vanadate in solution. Under aerated conditions the presence of atmospheric $\mathrm{CO}_{2}$ leads to the formation of $\mathrm{CaCO}_{3}$, providing an additional sink for aqueous $\mathrm{Ca}$. Under these conditions, much higher $\mathrm{V}$ concentrations are found in

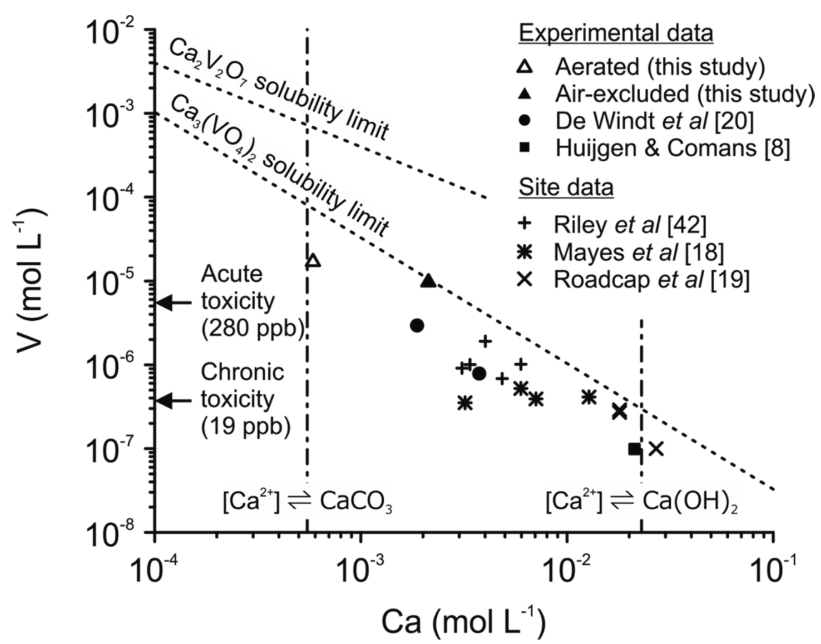

Figure 3. Plot of $[\mathrm{V}]$ versus $[\mathrm{Ca}]$ for selected experimental and site data (site data from refs 18, 19, and 42). Dashed lines marks the solubility limits for $\mathrm{Ca}_{3}\left(\mathrm{VO}_{4}\right)_{2}$ and $\mathrm{Ca}_{2} \mathrm{~V}_{2} \mathrm{O}_{7}$ at $20{ }^{\circ} \mathrm{C}$. ${ }^{45}$ Data plotting below the solubility limit is undersaturated with respect to that phase. Vertical dashed lines indicate $[\mathrm{Ca}]$ in solutions in equilibrium with calcite in contact with atmospheric $\mathrm{CO}_{2}$ or with $\mathrm{Ca}(\mathrm{OH})_{2}$, respectively (both at $20{ }^{\circ} \mathrm{C}$ ). Horizontal arrows indicate acute and chronic freshwater toxicity guideline limits ${ }^{43}$

solution, which in our experiments were still under-saturated with respect to $\mathrm{Ca}_{3}\left(\mathrm{VO}_{4}\right)_{2}$. As there is still dicalcium silicate available in the blocks, this indicates that the leachate composition is limited by kinetic effects related to slower dissolution of dicalcium silicate, partially protected by $\mathrm{Ca}-\mathrm{Si}-$ $\mathrm{H}$ in the altered region. In addition, calcium pyrovanadate $\left(\mathrm{Ca}_{2} \mathrm{~V}_{2} \mathrm{O}_{7}\right)$ solubility $\left(\log K_{\mathrm{sp}}=-12.0\right)$ and surface complexation reactions involving sorption to solids have been suggested as important in controlling $\mathrm{V}$ concentrations at $\mathrm{pH}<9.5 .^{8,38}$ In the aerated tests, however, where $\mathrm{pH}$ was $8.0, \mathrm{~V}$ concentrations were broadly consistent with $\mathrm{Ca}_{3}\left(\mathrm{VO}_{4}\right)_{2}$ solubility limits, and the data presented do not indicate that other phases or surface sorption processes were important in these tests.

Implications for Slag Weathering, Use, and Storage. Heap leaching of BOF slag by rainfall inevitably occurs during storage in large land-based repositories, and is often actively promoted to reduce the free lime content of BOF slag to permit its beneficial reuse. During the early stages of heap leaching free lime will be relatively abundant due to the high solid/solution ratios present $\left(8-10 \mathrm{~kg} \mathrm{~L}^{-1}\right)$. Aqueous $\mathrm{CO}_{2}$ species in the rainwater (from contact with atmosphere) will precipitate rapidly as it enters the waste, so $\mathrm{Ca}$ concentrations will be controlled largely by $\mathrm{Ca}(\mathrm{OH})_{2}$ equilibrium, producing highly alkaline, Ca-rich, leachates with corresponding low $\mathrm{V}$ concentrations (Figure 3.). However, the concentration of other trace metals solubilized at high $\mathrm{pH}$ (e.g., Al, Fe; Table 1) will potentially be maximized by these conditions.

In contrast, most lab-based leaching tests are performed at much lower solid/solution ratios (e.g., $0.01-0.1 \mathrm{~kg} \mathrm{~L}^{-1}$; this study, $\left.{ }^{20}\right)$. In such leaching tests the free lime phase can be exhausted. Thus, under air-excluded conditions, the $\mathrm{Ca}$ concentrations are controlled primarily by the balance of kinetic processes involving dicalcium silicate dissolution and equilibrium processes involving $\mathrm{Ca}-\mathrm{Si}-\mathrm{H}$ precipitation. Typically this produces order of magnitude lower $\mathrm{Ca}$ concentrations than found in $\mathrm{Ca}(\mathrm{OH})_{2}$ equilibrated water and correspondingly higher $\mathrm{V}$ concentrations due to the inverse 
relationship between $\mathrm{V}$ and $\mathrm{Ca}$ concentrations implied by $\mathrm{Ca}_{3}\left(\mathrm{VO}_{4}\right)_{2}$ solubility limit. Further, aerated leaching tests are often conducted to investigate the leaching end-point when the slag reaches equilibrium with $\mathrm{CO}_{2}$ species in the influent rainwater, although this will only occur on extremely long time sales in real waste heaps. Under aerated conditions, $\mathrm{Ca}$ concentrations are controlled by equilibrium with secondary $\mathrm{CaCO}_{3}$ precipitates that typically have low solubility (e.g., calcite $\log K_{\mathrm{sp}}=-8.44^{40}$ ) producing solutions with relatively low $\mathrm{Ca}$ concentrations. In this situation, much higher $\mathrm{V}$ concentrations are predicted (Figure 3).

One important implication is that these results may represent the sequence of slag leaching expected over time: first $\mathrm{CaO}$ / $\mathrm{Ca}(\mathrm{OH})_{2}$ dominated systems with low $\mathrm{V}$ concentrations; then calcium silicate/ $\mathrm{Ca}-\mathrm{Si}-\mathrm{H}$ dominated systems with higher $\mathrm{V}$ concentrations; and finally $\mathrm{CaCO}_{3}$ dominated systems with the potential for very high $\mathrm{V}$ concentrations. However, $\mathrm{pH}$ decrease is associated with depletion of reactive $\mathrm{V}$-containing calcium silicate phases (or, more accurately, the availability of these phases for dissolution as particle surfaces become protected by reaction products). Therefore, in a heap leaching situation in which the pore water is continually replaced, $\mathrm{V}$ release is kinetically limited and $\mathrm{V}$ concentrations are very unlikely to reach the solubility limit of calcium vanadate.

Release of $\mathrm{V}$ may also be influenced by the stability of secondary phases incorporating $\mathrm{V}$ (i.e., $\mathrm{Ca}-\mathrm{Si}-\mathrm{H}$ ) as well as long-term ( $>6$ month) stability of $\mathrm{V}$ incorporated into the less reactive dicalcium aluminoferrite phase. It has been suggested that in general these phases become increasingly soluble if the $\mathrm{pH}$ of their environment falls over time. ${ }^{41}$ A comparison of real site leachates also indicates that the heap weathering process can be very slow. Steel slags deposited in the UK and USA all produce high $\mathrm{pH}$ leachates that are largely dominated by $\mathrm{Ca}(\mathrm{OH})_{2}$ derived alkalinity and hence have low $\mathrm{V}$ concentrations (Figure $3^{18,19,42}$ ). Monitoring of leachates from BOF slag deposited at Consett U.K. has shown only modestly reduced alkalinity and $\mathrm{Ca}$ concentrations over 36 years since closure, leading to only slightly elevated $\mathrm{V}$ concentrations (compared to younger systems). ${ }^{18,42}$ Nevertheless, it should be noted that $\mathrm{V}$ concentrations in site leachates often exceed chronic toxicity thresholds $\left(19 \mu \mathrm{g} \mathrm{L}^{-1}\right)^{43}$ and that this work indicates that a reducing trend in alkalinity and $\mathrm{Ca}$ concentrations over time may not necessarily correspond to a reducing trend in $\mathrm{V}$ concentrations.

Overall, the presence of an altered region, and additional $\mathrm{CaCO}_{3}$ precipitate has positive implications for slag after-uses (e.g., as an aggregate) as the presence of an alteration rind may limit (or significantly slow) further dissolution, preventing significant alkalinity generation or metal leaching. On the other hand, calculations of the $\mathrm{CO}_{2}$ capture potential of BOF slag (often based on the reactivity of crushed powder samples or theoretical maximums based on whole mass conversion ${ }^{44}$ ) may overestimate both the total extent and the rates of carbonation observed in real-life situations.

\section{ASSOCIATED CONTENT}

\section{S Supporting Information}

The Supporting Information is available free of charge on the ACS Publications website at DOI: 10.1021/acs.est.7b00874.

Detailed SEM and XAS methods, EDS map and spectra, XRD plot, additional SEM images and SEM and XRF data (PDF)

\section{AUTHOR INFORMATION}

\section{Corresponding Author}

*Phone: +44 113 3437532; fax: +44 113 3435259; e-mail: i.t. burke@leeds.ac.uk.

ORCID ${ }^{\circ}$

Andrew J. Hobson: 0000-0002-3618-0096

Andrew W. Bray: 0000-0001-5399-6647

Ian T. Burke: 0000-0002-0484-568X

\section{Notes}

The authors declare no competing financial interest.

\section{ACKNOWLEDGMENTS}

This research was funded by a U.K. Natural Environment Research Council Ph.D. studentship to A.J.H. and U.K. NERC Grant NE/L01405X/1. We thank Diamond Light Source for access to beamline I18 (Grant SP12696) that contributed to the results presented here. We thank Tina Geraki and Fred Mosselmans (Diamond Light Source) for support during synchrotron time, and Andy Connelly, Lesley Neve, Stephen Reid, Richard Walshaw, and Duncan Hedges (all University of Leeds) for lab assistance, XRD, ICP-OES/MS, and SEM analysis, respectively.

\section{REFERENCES}

(1) Smil, V. Transforming the Twentieth Century: Technical Innovations and Their Consequences; Oxford University Press on Demand, 2006; Vol. 2.

(2) Engineering Employers Federation. UK Steel Key Stats Guide 2016. https://www.eef.org.uk/uk-steel/about-uk-steel (accessed Jun 8 2017).

(3) Yildirim, I. Z.; Prezzi, M. Chemical, Mineralogical, and Morphological Properties of Steel Slag. Adv. Civil Eng. 2011, 2011, $1-13$.

(4) Ober, J. A. Mineral Commodity Summaries 2016; US Geological Survey, 2016.

(5) Ahmedzade, P.; Sengoz, B. Evaluation of steel slag coarse aggregate in hot mix asphalt concrete. J. Hazard. Mater. 2009, 165 (13), 300-305.

(6) A Guide to the Use of Iron and Steel Slag in Roads; Australasian Slag Association, 2002; p 58. ISBN 09577051.

(7) Huijgen, W. J. J.; Comans, R. N. J. Mineral CO2 Sequestration by Steel Slag Carbonation. Environ. Sci. Technol. 2005, 39 (24), 96769682.

(8) Huijgen, W. J. J.; Comans, R. N. J. Carbonation of steel slag for $\mathrm{CO} 2$ sequestration: Leaching of products and reaction mechanisms. Environ. Sci. Technol. 2006, 40 (8), 2790-2796.

(9) Bobicki, E. R.; Liu, Q.; Xu, Z.; Zeng, H. Carbon capture and storage using alkaline industrial wastes. Prog. Energy Combust. Sci. 2012, 38 (2), 302-320.

(10) Doucet, F. J. Effective CO2-specific sequestration capacity of steel slags and variability in their leaching behaviour in view of industrial mineral carbonation. Miner. Eng. 2010, 23 (3), 262-269.

(11) Motz, H.; Geiseler, J. Products of steel slags an opportunity to save natural resources. Waste Manage. 2001, 21 (3), 285-293.

(12) Euroslag. Statistics 2012. http://www.euroslag.com/products/ statistics/2012/ (accessed Jun 8, 2017).

(13) Shen, D. H.; Wu, C. M.; Du, J. C. Laboratory investigation of basic oxygen furnace slag for substitution of aggregate in porous asphalt mixture. Constr. Build. Mater. 2009, 23 (1), 453-461.

(14) Tossavainen, M.; Engstrom, F.; Yang, Q.; Menad, N.; Lidstrom Larsson, M.; Bjorkman, B. Characteristics of steel slag under different cooling conditions. Waste Manage. 2007, 27 (10), 1335-1344.

(15) Piatak, N. M.; Parsons, M. B.; Seal, R. R. Characteristics and environmental aspects of slag: A review. Appl. Geochem. 2014, 57, 236. 
(16) Navarro, C.; Diaz, M.; Villa-Garcia, M. A. Physico-Chemical Characterization of Steel Slag. Study of its Behavior under Simulated Environmental Conditions. Environ. Sci. Technol. 2010, 44 (14), 5383-5388.

(17) Chaurand, P.; Rose, J.; Domas, J.; Bottero, J.-Y. Speciation of Cr and $\mathrm{V}$ within BOF steel slag reused in road constructions. J. Geochem. Explor. 2006, 88 (1-3), 10-14.

(18) Mayes, W. M.; Younger, P. L.; Aumonier, J. Hydrogeochemistry of alkaline steel slag leachates in the UK. Water, Air, Soil Pollut. 2008, 195 (1-4), 35-50.

(19) Roadcap, G. S.; Kelly, W. R.; Bethke, C. M. Geochemistry of extremely alkaline $(\mathrm{pH}>12)$ ground water in slag-fill aquifers. Groundwater 2005, 43 (6), 806-816.

(20) De Windt, L.; Chaurand, P.; Rose, J. Kinetics of steel slag leaching: Batch tests and modeling. Waste Manage. 2011, 31 (2), 225235.

(21) Proctor, D. M.; et al. Physical and chemical characteristics of blast furnace, basic oxygen furnace, and electric arc furnace steel industry slags. Environ. Sci. Technol. 2000, 34 (8), 1576-1582.

(22) Chaurand, P.; Rose, J.; Briois, V.; Olivi, L.; Hazemann, J.-L.; Proux, O.; Domas, J.; Bottero, J.-Y. Environmental impacts of steel slag reused in road construction: A crystallographic and molecular (XANES) approach. J. Hazard. Mater. 2007, 139 (3), 537-542.

(23) Barceloux, D. G. Vanadium. J. Toxicol., Clin. Toxicol. 1999, 37 (2), 265-78.

(24) Environment Agency. EA Bespoke permit 2014 Permit for Scunthorpe Aggregate processing. Permit number EPR/LP3537VV/ A001, 2014.

(25) Plas, L.v.d.; Tobi, A. C. A chart for judging the reliability of point counting results. Am. J. Sci. 1965, 263 (1), 87-90.

(26) Ravel, B.; Newville, M. ATHENA, ARTEMIS, HEPHAESTUS: data analysis for X-ray absorption spectroscopy using IFEFFIT. J. Synchrotron Radiat. 2005, 12 (4), 537-41.

(27) Allen, A. J.; Thomas, J. J.; Jennings, H. M. Composition and density of nanoscale calcium-silicate-hydrate in cement. Nat. Mater. 2007, 6 (4), 311-316.

(28) Richardson, I. G. The nature of C-S-H in hardened cements. Cem. Concr. Res. 1999, 29 (8), 1131-1147.

(29) Gard, J. A.; Taylor, H. F. W. Calcium silicate hydrate (II) ("C-SH(II)"). Cem. Concr. Res. 1976, 6 (5), 667-677.

(30) Chen, J. J.; Thomas, J. J.; Taylor, H. F. W.; Jennings, H. M. Solubility and structure of calcium silicate hydrate. Cem. Concr. Res. 2004, 34 (9), 1499-1519.

(31) Wu, S.; Xue, Y.; Ye, Q.; Chen, Y. Utilization of steel slag as aggregates for stone mastic asphalt (SMA) mixtures. Build. Environ. 2007, 42 (7), 2580-2585.

(32) Chaurand, P.; et al. New methodological approach for the vanadium $\mathrm{K}$-edge $\mathrm{X}$-ray absorption near-edge structure interpretation: Application to the speciation of vanadium in oxide phases from steel slag. J. Phys. Chem. B 2007, 111 (19), 5101-5110.

(33) Colville, A. A.; Geller, S. The crystal structure of brownmillerite, Ca2FeAlO5. Acta Crystallogr., Sect. B: Struct. Crystallogr. Cryst. Chem. 1971, 27 (12), 2311-2315.

(34) Taylor, H. F. W. Cement Chemistry; Thomas Telford, 1997.

(35) Peacock, C. L.; Sherman, D. M. Vanadium(V) adsorption onto goethite (alpha-FeOOH) at $\mathrm{pH} 1.5$ to 12 : A surface complexation model based on ab initio molecular geometries and EXAFS spectroscopy. Geochim. Cosmochim. Acta 2004, 68 (8), 1723-1733.

(36) Wehrli, B.; Stumm, W. Vanadyl in Natural-Waters - Adsorption and Hydrolysis Promote Oxygenation. Geochim. Cosmochim. Acta 1989, 53 (1), 69-77.

(37) Taylor, H. F. W. Nanostructure of C-S-H: Current status. Adv. Cem. Based Mater. 1993, 1 (1), 38-46.

(38) Schindler, M.; Hawthorne, F. C.; Baur, W. H. A CrystalChemical Approach to the Composition and Occurrence of Vanadium Minerals. Can. Mineral. 2000, 38 (6), 1443-1456.

(39) Cornelis, G.; Johnson, C. A.; Van Gerven, T.; Vandecasteele, C. Leaching mechanisms of oxyanionic metalloid and metal species in alkaline solid wastes: A review. Appl. Geochem. 2008, 23 (5), 955-976.
(40) Lide, D. R. CRC Handbook of Physics and Chemistry; CRC Press, 2001.

(41) Engström, F.; Adolfsson, D.; Samuelsson, C.; Sandstrom, Å.; Björkman, B. A study of the solubility of pure slag minerals. Miner. Eng. 2013, 41, 46-52.

(42) Riley, A. L.; Mayes, W. M. Long-term evolution of highly alkaline steel slag drainage waters. Environ. Monit. Assess. 2015, 187 (7), No. 4693-1, DOI: 10.1007/s10661-015-4693-1.

(43) Buchman, M. F. S. W. NOAA Screening Quick Reference Tables; Office of Response and Restoration Division, National Oceanic and Atmospheric Administration: Washington, DC, 2006; p 34.

(44) Renforth, P.; Washbourne, C.-L.; Taylder, J.; Manning, D. A. C. Silicate Production and Availability for Mineral Carbonation. Environ. Sci. Technol. 2011, 45 (6), 2035-2041.

(45) Allison, J. D., Brown, D. S.; Novo-Gradac, K. J. MINTEQA2/ PRODEFA2, a Geochemical Assessment Model for Environmental Systems, version 3.0 user's manual; Environmental Research Laboratory, Office of Research and Development, US Environmental Protection Agency, 1991. 